\title{
Study of Phenolic Compounds and Antimicrobial Activity of Lavandula angustifolia L. Flowers Macerates
}

\author{
GABRIELA STANCIU ${ }^{1}$, FLORIN AONOFRIESEI ${ }^{2}$, SIMONA LUPSOR ${ }^{1 *}$, ANTOANELA POPESCU ${ }^{3}$, RODICA SIRBU 3 \\ ${ }^{1} O$ vidius University of Constanta, Department of Chemistry and Chemical Engineering, 124 Mamaia Blvd., 900527, Constanta, \\ Romania \\ ${ }^{2}$ Ovidius University of Constanta, Faculty of Natural Sciences and Agricultural Sciences,124 Mamaia Blvd., 900527, Department \\ of Natural Sciences, Romania \\ ${ }^{3}$ Ovidius University of Constanta, Department of Pharmaceutical Science, 124 Mamaia Blvd., 900527, Constanta, Romania
}

\begin{abstract}
Studies of total phenolic content and identification and quantification of phenolic compounds by HPLC-DAD from hydro-alcoholic and alcoholic macerates of Lavandula angustifolia $L$ flowers from Dobrogea area are reported. The total phenolic content and the phenolic profile have been measured using Folin-Ciocalteau method, respectively adapted USP3O HPLC method in macerates of Lavandula angustifolia L flowers after 5 days of contact with either methanol (M1) or methanol: water 1: 1 (V:V) mixture (M2). The values of TPC show that macerate $M 2$ is more rich in phenolic compounds (3520 mg/100g d.w.), than in the case of macerate M1 (2860 mg/100 g d.w.). The obtained data of phenolic compounds determined by HPLC-DAD method were compared with the available authentic standards. Four individual phenolic compounds were found in macerate M1 and six individual phenolic compounds in macerate M2. Among gallic acid and chlorogenic acid, as major phenolic compounds, high concentrations of ellagic acid in M2 (514.249 mg/100 gd.w.) and M1 (499.487 mg/100g d.w.) were found. The antimicrobial activity of tested macerates indicates that Lavandula sp. has a moderate effect on the bacterial and Candida growth.
\end{abstract}

Keywords: Lavandula sp., USP30-HPLC method, Folin-Ciocalteu method, antimicrobial activity.

Lavandula angustifolia L. is an important crop utilized to obtain medicinal and aromatic (commercial valuable) essential oil [1]. Many studies shown that lavender oil, obtained from the flowers of Lavandula angustifolia, is composed mainly of linalyl acetate, linalool, lavandulol, 1,8-cineole, lavandulyl acetate and camphor [1-3].

The genus Lavandula belongs to the 'Labiatae' family which geographically grows mostly in Europe and comprises many different species. The agricultural practices directly influence the secondary metabolites produced in the plants, and thus the quality of polyphenolic compounds [4-6]. Lavadula species biosynthesizes and accumulates its volatile compounds primary in specialized secretory capitate and peltate oil glands located abundantly on the surface of the calyx and secondary on the leaves [1-2, 6-7]. Generally, the flower is an important part of plant which contains a great variety of natural antioxidants such as flavonoids, phenolic acids, anthocyanin and many other precious phenolic compounds [3].

Lavender is well known from ancient times for its medicinal uses as sedative, cholagogue and antiseptic [3] . Due to its content in essential oils, triterpenes, flavonoids and other polyphenolic compounds Lavandula species are widely used in food industry and cosmetics [4]. Lavandula angustifolia presents a wide range of useful therapeutically properties, such as: antioxidant [1-2], antifungal and bactericidal [6], cytotoxic [7], antiseptic, antiinflammatory, analgesic [7-8], and other useful properties for pharmaceutical industries, food industries and cosmetics industries. Antimicrobial activity of the essential oil extracted from lavender has been well documented over time [9-10]. Besides essential oils, other components of Lavandula may have substantial antimicrobial properties [11].

\footnotetext{
*email: sgutaga@univ-ovidius.ro, Phone:_402416600488
}

Therefore, we found interesting to determine the amount of polyphenolic compounds present in Lavandula sp. flowers from Dobrogea area and to test it against both Gram negative bacteria, Gram positive bacteria as well as against several Candida strains in order to estimate their antimicrobial effect. The total content of phenolic compounds from two different types of macerates was measured using the Folin-Ciocalteu method and the phenolic profile of studied macerates was established using HPLC-DAD method. The antimicrobial activity of lavender extract was established by difusimetric well method and minimal inhibitory activity (MIC).

\section{Experimental part}

Plant materials

Lavandula angustifolia $L$ flowers were collected in August and September 2017, from organic culture in Topraisar, Constanta County, Romania. The plant was dried at ambient temperature until constant weight was achieved.

\section{Chemicals}

All used reagents were of analytical reagent grade. Gallic acid was purchased from Fluka (Buchs, Switzerland) and Folin - Ciocalteu reagent from Merck (Darmstadt, Germany). The solution of gallic acid (standard phenolic compound) $1 \times 10^{-2} \mathrm{~mol} \mathrm{~L}^{-1}$ was prepared by dissolving $0.1881 \mathrm{~g}$ of gallic acid in $100 \mathrm{~mL}$ ethanol. Folin - Ciocalteu reagent was diluted with distilled water $1: 2(\mathrm{~V}: \mathrm{V})$.

\section{Apparatus}

The chromatographic determinations of phenolic compounds were performed with HPLC-DAD system Agilent 1200 with quaternary pump, DAD, autosampler. 
Spectrometric measurements were carried out using a UVVIS JASCO V550 scanning spectrophotometer.

\section{Sample extract}

Extraction 1 was achieved by maceration of $5 \mathrm{~g}$ of dried plant in $60 \mathrm{~mL}$ methanol at room temperature and protected from light during five days. The mixture was strongly shaken several times every day. A sample of 39 $\mathrm{mL}$ of macerate (M1) was separated by filtration and then analysed.

Extraction 2 was achieved by maceration of $5 \mathrm{~g}$ of dried plant product in $60 \mathrm{~mL}$ methanol: water 1:1 (V:V) mixture in similar conditions as extraction 1. After 5 days of maceration a sample of $33 \mathrm{~mL}$ of macerate (M2) was separated by filtration and immediately analysed.

Identification and quantification of phenolic compounds by HPLC-DAD

The resulted macerates solutions were analysed by HPLC.

Adapted USP30 HPLC method [12-13] was used for separation, identification and quantification of the phenolic compounds.

Separation was carried out on Zorbax Eclipse XDB-C18 column: 250 mm, 4,6 mm; 5 um (Agilent Technologies). The gradient elution was accomplished using phosphoric acid $0.1 \%$ in water (solvent $A$ ) and acetonitrile (solvent B) as presented in table 1.

Table 1

THE GRADIENT OF ELUTION SOLVENTS

\begin{tabular}{|c|c|c|}
\hline $\begin{array}{c}\text { Time } \\
(\mathrm{min} .)\end{array}$ & $\begin{array}{c}\text { Solvent A, } \\
\%\end{array}$ & $\begin{array}{c}\text { Solvent B, } \\
\%\end{array}$ \\
\hline $0-13$ & 90 & 10 \\
\hline 13 & 78 & 22 \\
\hline 13 & 78 & 22 \\
\hline 14 & 60 & 40 \\
\hline 17 & 60 & 40 \\
\hline 17.5 & 90 & 10 \\
\hline 22 & 90 & 10 \\
\hline
\end{tabular}

The parameters of chromatographic process were: 1.5 $\mathrm{mL} / \mathrm{min}$ the flow rate, $20 \mu \mathrm{L}$ injection volume and $22 \mathrm{~min}$ analysis time.

Quantification of phenolic acid was performed using absorbance measurements at $310 \mathrm{~nm}$ and $35^{\circ} \mathrm{C}$. The retention times and DAD spectra were compared to available authentic standards.
A mixture of standard solutions in $70 \%$ methanol was used having the following concentrations:

$37 \mathrm{mg} / \mathrm{mL} \mathrm{E}$ - resveratrol, $0.22 \mathrm{mg} / \mathrm{L} \mathrm{Z}$ - resveratrol, 0.36 $\mathrm{mg} / \mathrm{mL}$ caffeic acid, $0.37 \mathrm{mg} / \mathrm{mL}$ chlorogenic acid, $0.58 \mathrm{mg} /$ $\mathrm{mL}$ cinnamic acid, $0.42 \mathrm{mg} / \mathrm{mL}$ vanillin, $0.39 \mathrm{mg} / \mathrm{mL}$ gallic acid, $0.48 \mathrm{mg} / \mathrm{mL}$ ferulic acid, $0.34 \mathrm{mg} / \mathrm{mL}$ 3-methylgalic acid, $0.43 \mathrm{mg} / \mathrm{mL}$ ellagic acid, $0.51 \mathrm{mg} / \mathrm{mL}$ p-coumaric acid.

The retention times of standard solutions have been determined (table 2). Standard deviations of retentions time were obtained after statistical processing of the 6 injections (soft SPSS 10).

Table 2

THE RETENTION TIME OF STANDARDS

\begin{tabular}{|l|c|}
\hline Standards & Retention time \pm SD \\
\hline gallic acid & $0.990 \pm 0.025$ \\
\hline $3-0-$-methylgallic acid & $2.606 \pm 0.008$ \\
\hline chlorogenic acid & $3.501 \pm 0.015$ \\
\hline caffeic acid & $4.598 \pm 0.036$ \\
\hline vanillin & $6.919 \pm 0.051$ \\
\hline$p$-coumaric acid & $7.187 \pm 0.019$ \\
\hline feluric acid & $8.565 \pm 0.058$ \\
\hline$E$ - resveratrol & $14.467 \pm 0.017^{-}$ \\
\hline ellagic acid & $15.303 \pm 0.027^{-}$ \\
\hline$Z$ - resveratrol & $15.751 \pm 0.058$ \\
\hline cinnamic acid & $15.867 \pm 0.007$ \\
\hline
\end{tabular}

Identification and quantitative determination of the active constituents from samples extractive solution were done by comparing the samples chromatograms with chromatogram of standards mixture (fig. 1).

\section{Total phenolic content (TPC)}

The total phenols were estimated according to the FolinCiocalteu method [14-16]. During the procedure in a $5 \mathrm{~mL}$ extractive solution were added $1 \mathrm{~mL}$ of Folin-Ciocalteureagent $1: 2(\mathrm{~V}: \mathrm{V})$ and $1 \mathrm{~mL}$ of $20 \%(\mathrm{w} / \mathrm{v}) \mathrm{Na}_{2} \mathrm{CO}_{3}$ aqueous solution; after 10 min the volume was brought to mark up to $50 \mathrm{~mL}$ with distilled water. After 30 min of incubation at $25^{\circ} \mathrm{C}$ the absorbance was measured at $681 \mathrm{~nm}$; the total phenols concentration was determined using the calibration curve plotted with gallic acid as standard. The calibration curve was linear in the range of $0.68-4.76 \mathrm{mg}$ $/ L \mathrm{GAE}\left(\mathrm{R}^{2}=0.9973\right)$ where $\mathrm{GAE}$ is gallic acid equivalents. Total phenols content of lavender extract was expressed as $\mathrm{mg}$ of gallic acid equivalents per $100 \mathrm{~g}$ of dry weight (mg GAE/100g d.w.). All samples were performed in triplicate and the mean value was reported.

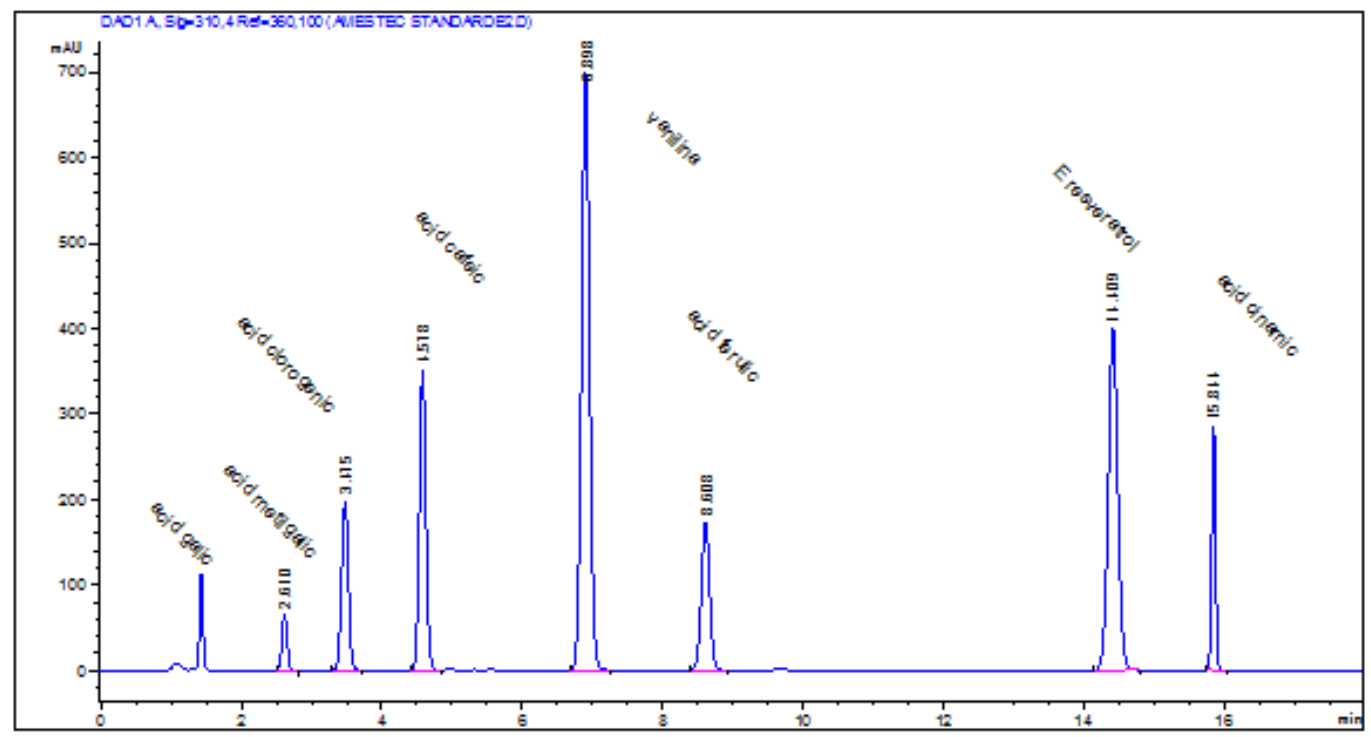

Fig.1. HPLC chromatogram of standards mixture 


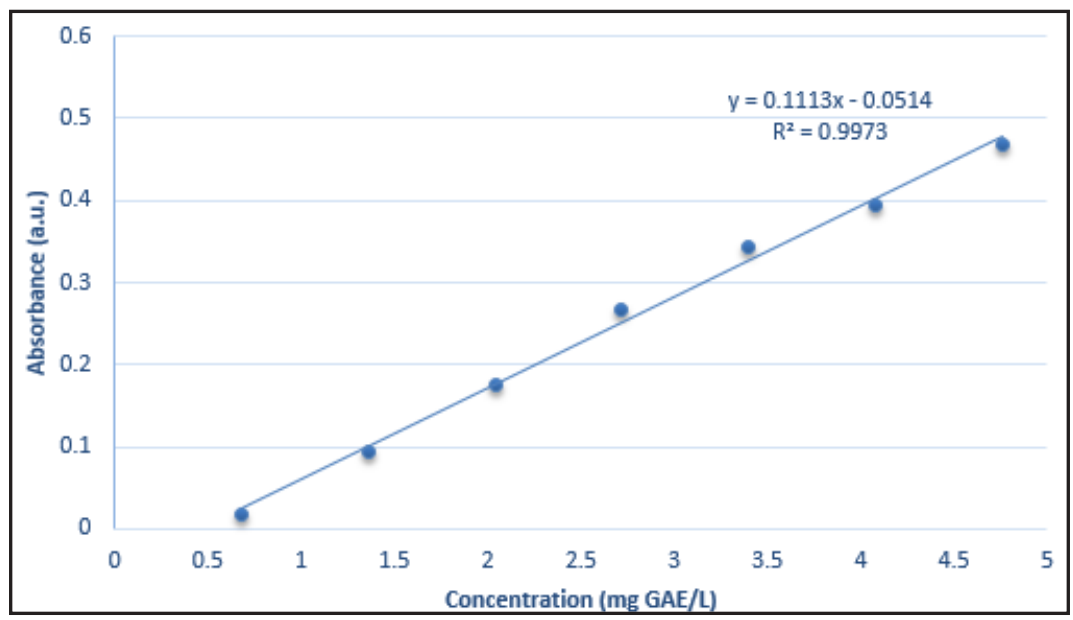

Fig.2. Calibration curve of gallic acid in the range of $0.68-4.76 \mathrm{mg} \mathrm{GAE} / \mathrm{L}$ at $681 \mathrm{~nm}$

\section{Calibration curve}

For calibration curve the volumes of $1 \mathrm{~mL}, 2 \mathrm{~mL}, 3 \mathrm{~mL}$, $4 \mathrm{~mL}, 5 \mathrm{~mL}, 6 \mathrm{~mL}$ and $7 \mathrm{~mL}$ of gallic acid standard solution were used. To plot the calibration curve the Folin-Ciocalteu reagent $1: 2$ was added in $50 \mathrm{~mL}$ calibrated flasks to different volumes of standard gallic acid solution, then 1 $\mathrm{mL}$ sodium carbonate solution $20 \%$, was added and after 10 min the volume was made up to $50 \mathrm{~mL}$ with distilled water. Each sample was homogenized and let $30 \mathrm{~min}$ at room temperature for the colour stabilization and after that the absorbance was read at $681 \mathrm{~nm}$. (fig. 2)

For TPC analysis, volumes of $10 \mathrm{~mL}$ of each macerate were transferred into $25 \mathrm{~mL}$ volumetric flask and brought to the mark with the same solvent previously used for maceration operation. To measure the total phenols content, samples of $1 \mathrm{~mL}$ of previously diluted solutions were added in $25 \mathrm{~mL}$ calibrated flasks, then $1 \mathrm{~mL}$ FolinCiocalteu reagent $1: 2(\mathrm{~V}: \mathrm{V}), 1 \mathrm{~mL}$ sodium carbonate solution $20 \%$ and the process was the same like those used for calibration.

\section{Difusimetric evaluation of lavender macerates (M1 and M2) activity}

Antibacterial effect of lavender macerates (M1 and M2) has been estimated by difusimetric well method. Bacterial strains were grown overnight on Tryptone Soy Broth (TSB Oxoid) [composition ( $\mathrm{g} / \mathrm{L}$ ): glucose, 2.5; pancreatic digest of casein, 1,0; enzymatic digest of soybean, 3.0; sodium chloride, 5.0; di-potassium hydrogen phosphate, $2.5 ; \mathrm{pH}=$ 7.3] for 16-24h. Candida strains were grown on Sabouraud Dextrose Broth (Oxoid) [composition ( $\mathrm{g} / \mathrm{L}$ ): bactopeptone, 10.0; dextrose, 40.0; $\mathrm{pH}=5.6$ ] for $16-24 \mathrm{~h}$.

The bacterial strains were inoculated by spreading the overnight culture on Muller Hinton agar (MHA - Oxoid) [composition ( $\mathrm{g} / \mathrm{L}$ ): casein hydrolysate, 17.5; beef extract, 3.0; starch, 1.5; agar-agar, 17.0, $\mathrm{pH}=7.3]$. The difusimetric testassay for Candidawas performed in very similar manner using Sabouraud Dextrose Agar (Oxoid) [composition ( $\mathrm{g} /$ L): bactopeptone, 10.0; dextrose, 40.0; agar, 12.0, $\mathrm{pH}=5.6]$. After inoculation by spreading, the wells $(d=6 \mathrm{~mm})$ were performed on solid media in aseptic conditions. Lavender macerates M1 and M2 were tested against seven bacterial strains and three Candida strains (table 3).

\section{Estimation of Minimal Inhibitory Concentration (MIC)}

The extracts were diluted (from 1:4 to 1:20) in sterile Muller Hinton Broth (bacterial strains) and Sabouraud Dextrose Broth (Candida strains). Test tubes containing culture medium and extracts were inoculated with $10 \mathrm{iL}$ of cultures grown for $24 \mathrm{~h}$. To estimate the effect of solvent, similar dilution were made with methanol and methanol: water 1:1 (V:V) mixture without extracted material and
Table 3

MICROORGANISMS USED TO ASESS THE INHIBITORY ACTIVITY OF LAVANDULA MACERATES M1 AND M2

\begin{tabular}{|l|l|}
\hline Strains & Observations \\
\hline Staphylococcus $s p$. & Hemolytic strains \\
\hline Streptococcus sp. & Beta-hemolytic strain \\
\hline E. coli $I^{-}$ & $\begin{array}{l}\text { Isolated from urinary } \\
\text { tract infection (UTI) }\end{array}$ \\
\hline E. coli 1 & Isolated from UTI \\
\hline E. coli 1 & Isolated from UTI \\
\hline E. coli 2 & Isolated from UTI \\
\hline Klebsiella s. & Isolated from UTI \\
\hline Candida albicans $I^{-}$ & $\begin{array}{l}\text { Isolated from mouth } \\
\text { infection (MI) }\end{array}$ \\
\hline Candida albicans 1 & Isolated from MI \\
\hline Candida albicans 2 & Isolated from MI \\
\hline
\end{tabular}

having the same concentrations as the solvents used for extraction of phenols from Lavandula angustifolia $\mathrm{L}$. flowers. The inhibitory values of methanol and methanol water $1: 1(\mathrm{~V}: \mathrm{V})$ were then subtracted from final calculations of MIC.

\section{Results and discussions}

Phenolic compounds separation, identification and quantification

In table 4 are presented the values of phenolic compounds determined by HPLC-DAD method and compared with the available authentic standards.

By comparing to the available authentic standards used for determinations, four individual phenolic compounds were found in tested macerate $M 1$ and six individual phenolic compounds in macerate $\mathrm{M} 2$. A high concentration of gallic acid was found in both analysed macerates, but in the hydro-alcoholic macerate M2 the concentration is much higher than the one obtained for alcoholic macerate M1 (table 4). It's well known that gallic acid has mutagenic and teratogenic effect [17-21].

Significant amounts of ellagic acid were found in both macerates. The difference of ellagic acid values concentration in the analysed macerates indicates a higher concentration in M2 (514.249 mg/100 g d.w.) than in M1 ( $499.487 \mathrm{mg} / 100 \mathrm{~g}$ d.w.). Ellagic acid has antiproliferative properties and antioxidant properties related with its ability to directly inhibit the DNA binding of certain carcinogens, including nitrosamines and polycyclic aromatic hydrocarbons [1-2]. Also, ellagic acid has a chemoprotective effect in cellular models by reducing oxidative stress [19-21].

Significant amounts of chlorogenic acid were determined for both macerates. Macerate M2 showed a higher concentration of chlorogenic acid than macerate 


\begin{tabular}{|l|c|c|c|c|}
\hline \multirow{2}{*}{ Phenolic compound } & \multicolumn{2}{|c|}{ M1 } & \multicolumn{2}{c|}{$\mathrm{M}$} \\
\cline { 2 - 5 } & $\begin{array}{c}\mathrm{mg} / \\
100 \mathrm{~g} \text { d.w. }\end{array}$ & $\mathrm{wt} \%$ & $\begin{array}{c}\mathrm{mg} / \\
100 \mathrm{~g} \text { d.w. }\end{array}$ & $\mathrm{wt} \%$ \\
\hline Chlorogenic acid & 301.625 & 18.001 & 570.730 & 28.987 \\
\hline Caffeic acid & - & - & 3.952 & 0.201 \\
\hline Gallic acid & 520.760 & 31.078 & 767.938 & 39.003 \\
\hline Ellagic acid & 499.487 & 29.809 & 514.249 & 26.119 \\
\hline Cinnamic acid & 353.763 & 21.112 & 99.480 & 5.053 \\
\hline p-Coumaric acid & - & - & 12.550 & 0.637 \\
\hline Total Phenols & 1675.635 & 100 & 1968.900 & 100 \\
\hline
\end{tabular}

Table 4

CONTENTS (mg/100g d.w.) AND WEIGHT PERCENTAGES (wt\%) OF INDIVIDUAL PHENOLIC COMPOUNDS OF TESTED LAVANDULA DETERMINED BY HPLC-DAD

\begin{tabular}{|c|c|c|c|c|c|}
\hline \multirow[t]{2}{*}{ No. } & \multirow[t]{2}{*}{ Sample } & \multirow[t]{2}{*}{$\begin{array}{l}\text { GAE } \\
\mathrm{mg} / 100 \mathrm{~g} \mathrm{~d} w\end{array}$} & \multirow{2}{*}{$\begin{array}{c}\text { Percent of measured } \\
\text { individual phenols by } \\
\text { HPLC versus TPC, } \\
\text { wt } \%\end{array}$} & \multicolumn{2}{|c|}{$\begin{array}{l}\text { The major individual determined } \\
\text { phenols in lavender }\end{array}$} \\
\hline & & & & Phenolic compound & $w t \%$ \\
\hline \multirow[t]{2}{*}{1} & \multirow[t]{2}{*}{ M1 } & \multirow[t]{2}{*}{2860} & \multirow[t]{2}{*}{58.59} & Ellagic acid & 17.46 \\
\hline & & & & Gallic acid & 18.210 \\
\hline \multirow[t]{2}{*}{2} & \multirow[t]{2}{*}{$\mathrm{M} 2$} & \multirow[t]{2}{*}{3520} & \multirow[t]{2}{*}{55.93} & Gallic acid & 21.86 \\
\hline & & & & Chlorogenic acid & 16.21 \\
\hline
\end{tabular}

Table 5

THE WEIGHT PERCENTAGES (\%) OF TOTAL PHENOLS AND OF MAIOR PHENOLIC COMPOUNDS DETERMINED IN LAVANDULA
M1. It is known that chlorogenic acid slightly reduces blood pressure, but also it has anti-inflammatory action and is studied as a possible chemical sensitizer involved in respiratory allergy [3].

In the case of cinnamic acid it can be noticed that methanolic macerate of lavender M1 presents a higher concentrantion ( $353.763 \mathrm{mg} / 100 \mathrm{~g} \mathrm{d.w.)}$ than the hydroalcoholic macerate (M2).

p-Coumaric acid and caffeic acid were identified only in hydro-alcoholic macerate (M2) of Lavandula angustifolia L. flowers.

From the obtained results it is obviously that when methanol : water 1:1 (V:V) (M2) mixture was used as solvent, the extraction of phenolic compounds from Lavandula angustifolia L. flowers proved to be more efficient than the case when extraction of phenols was done with methanol p.a. (M1). The concentration of all phenolic compounds present in Lavandula angustifolia L. flowers extract proves that lavender is a precious source of antioxidants with valuable benefits for human health.

\section{Total phenolic content (TPC)}

The results of total phenolic contents from the analysed macerates of Lavandula sp., expressed as $\mathrm{mg} / 100 \mathrm{~g}$ dry weight, are presented in table 5. Also, the weight percentage $(\%)$ of total phenols was reported to the major phenolic compounds determined by HPLC-DAD.

The obtained values in case of TPC analysis indicate that Lavandula angustifolia $L$ has a high amount of phenolic compounds comparable to other literature data [17-21].

The results for TPC indicates that $L$ avandula angustifolia $L$ macerate $M 2$, therefore when as solvent was used methanol: water $1: 1(\mathrm{~V}: \mathrm{V})$, is more efficient for phenolic compounds extraction than in case of macerate M1, when as solvent was used only methanol. The difference between the values of total phenolic compounds determined by both methods for both macerates is due to the presence of other phenolic acids that were not determined in the applied HPLC-DAD conditions.

\section{Difusimetric evaluation of lavender extracts activity}

The activity of both macerates was almost similar on average, ranging between 3.4-3.5 mm of inhibition zones. However, individual species demonstrated a distinct behaviour with more variable responses and inhibition zones, ranging from $2 \mathrm{~mm}$ ( $E$. coli 2) to $6 \mathrm{~mm}$ (Streptococcus sp.) (table 6).

\section{Table 6}

INHIBITORY EFFECT OF LAVANDULA MACERATE ON BACTERIAL AND CANDIDA STRAINS (MM INHIBITION ZONE)

\begin{tabular}{|c|c|c|c|}
\hline strains & M1 & $\mathrm{M} 2$ & $\begin{array}{l}\text { Average value } \\
\text { of inhibition } \\
\text { zone/strain }\end{array}$ \\
\hline Staphylococcus $s p$. & 5 & 5 & 5 \\
\hline Streptococcus sp. & 6 & 6 & 6 \\
\hline E. colil & 3 & 3 & 3 \\
\hline E. coli $\mathrm{I}$ & 2 & 3 & 2.5 \\
\hline E. coli & 3 & 3 & 3 \\
\hline E. $\operatorname{coli} 2$ & 2 & 2 & 2 \\
\hline Klebsiella sp & 4 & 4 & 4 \\
\hline Candida albicans $Y$ & 3 & 3 & 3 \\
\hline Candida albicans $l^{-}$ & 3 & 3 & 3 \\
\hline Candida albicans 2 & 3 & 3 & 3 \\
\hline $\begin{array}{l}\text { Average value of inhibition } \\
\text { zone/extract }\end{array}$ & 3.4 & 3.5 & \\
\hline
\end{tabular}

Except of Staplycococcus and Streptococcus strains when it was recorded a lower value, MIC was almost uniform for other microorganisms (table 7). Both diffusimetric test and MIC indicated a moderate antimicrobial activity of lavender macerates. In spite of this, the macerates might be useful in cosmetic formulations where they can act as bacteriostatic agents and as such they can prevent contamination and spreading of undesired microorganisms. Moreover, their activity might be increased in ointments and creams where other ingredients may act in a synergistic way and improve their antimicrobial potential.

The obtained data proved that hydro-methanolic and methanolic macerates of Lavandula sp. had a moderate

Table 7

MIC OF LAVANDULA MACERATES (EXPRESSED AS DILLUATION UNITS: $0.25=1 / 4 ; 0.20=1 / 5,0.10=1 / 10$

\begin{tabular}{|l|l|l|}
\hline Strains & $\mathrm{M1}$ & $\mathrm{M} 2$ \\
\hline Staphylococcus sp. & 0.05 & 0.10 \\
\hline Streptococcus sp. & 0.05 & 0.10 \\
\hline E. coli I & 0.20 & 0.20 \\
\hline E. coli I & 0.20 & 0.20 \\
\hline E. coli I & 0.20 & 0.20 \\
\hline E. coli 2 & 0.20 & 0.20 \\
\hline Klebsiella sp & 0.20 & 0.20 \\
\hline Candida albicans $Y^{-}$ & 0.20 & 0.20 \\
\hline Candida albicans 1 & 0.20 & 0.25 \\
\hline Candida albicans 2 & 0.20 & 0.25 \\
\hline
\end{tabular}


effect on the bacterial and Candida growth. Their antimicrobial activity was more or less in the same range as other plants products. Macerates of lavender might be used in different pharmaceutical formulations to control contamination and microbial spoilage due to their microbiostatic potential.

\section{Conclusions}

The extracts of Lavandula angustifolia L. flowers as hydro-methanolic and methanolic macerates have been analysed to find phenolic composition and to test their antimicrobial activity. Six individual phenolic compounds were identified and quantified by HPLC-DAD in the hydromethanolic macerate M2 of lavender, while in the methanolic macerate M1 only four phenolic compounds were found. The presence of high concentrations of ellagic acid in both macerates together with gallic acid and chlorogenic acid are remarkable for improving the benefits of using Lavandula sp. macerates also as chemoprotective agent.

The Lavandula sp. macerates present high concentrations of total phenolic contents, but also in this case it was noticed that hydro-methanolic macerate (M2) was much richer in phenolic compounds than the one when for maceration was performed only with methanol (M1). This indicates that the comprising solvent methanol: water 1:1 ( V:V) mixture is more efficient for phenolic compounds extraction.

The antimicrobial activity of hydro-methanolic (M2) and methanolic (M1) macerates indicates that Lavandula sp. has a moderate effect on the bacterial and Candida growth. Comparing to other plants products, the antimicrobial activity of lavender macerates was more or less in the same range. Therefore, macerates of lavender might be used in different pharmaceutical commercial products with microbiostatic potential.

In general, the lavender use may represent an alternative source of antioxidants with anti-microbial, anti-cancer, anti-inflammatory and anti-diabetic effects.

\section{References}

1.EL HAMDAOUI, A.E., MSANDA, BOUBAKER, F.H., LEACH, D., BOMBARDA, I., VANLOOT, P., AOUAD, A.E., ABBAD, A., BOUDYACH, E.H., ACHEMCHEM, F., ELMOSLIH, A., AIT BEN AOUMAR, A., EL MOUSADIK, A., Biochemical Systematics and Ecology, 76, 2018, p. 1.
2.HASSIOTIS, C.N, TARANTILIS, P.A.,D. DAFERERA, D., POLISSIOU, M.G. Industrial Crops and Products, 32, 2010, p. 77.

3.WICHTL, M., Herbal Drugs and Phytopharmaceuticals, 3th ed.; Medpharm: Stuttgart, 2004.

4.TIWARI, B.K., VALDRAMIDIS, V.P., O'DONNELL, C.P., MUTHUKUMARAPPAN, K.; BOURKE, P., CULLEN, P.J., J. Agric. Food Chem., 57, 2009, p. 5987.

5.W AGNER, H., ULRICH-MERZENICH, G., Phytomedicine, 16, 2009, p. 97.

6.DEANS, S.G., Antimicrobial properties of lavender volatile oil. Chapter in Lavender: The Genus Lavandula, LIS-BALCHIN, M., Ed., CRC Press: London, 2002, p. 171.

7.MOON, T., WILKINSON, J.M., CAVANAGH, H.M.A., Int. J . Aromather., 16, 2006, p. 9.

8.KALEMBA, D., KUNICKA, A., Curr. Med. Chem., 10, 2003, p. 813. 9.DORMAN, H.J., DEANS, S.G., J. Appl. Microbiol., 88, 2000, p. 308. 10.SOKOVIÆ, M., GLAMOĖLIJA, J., MARIN, P.D., BRKIÆE, D., GRIENSVEN, L.J ., Molecules, 15, 2010, p. 7532.

11.CUSHNIE, T.P.T., LAMB, A.J., Int. J. Antimicrob. Agents, 26, 2005, 343.

12.*** NF 25, United States Pharmacopeia and the National Formulary (USP 30/NF 25), Rockville (MD), The United States Pharmacopeial Convention Inc., 914, 2007.

13.STANCIU, G., AONOFRIESEI, F., CRISTACHE, N., LUPSOR, S., Rev. Chim.(Bucharest), 68, no.8, 2017, p. 1752.

14.POPOV, I. N., LEWIN, G., Photosintesitized Chemiluminiscence. Its Medical and Industrial Applications for Antioxidizability Tests. Chapter in: Chemiluminiscence in Analytical Chemistry, A. M. GarciaCampana, WRG Baeyens (Eds), Marcel Decker Inc., New York, 2001. 15.STANCIU, G., CHIRILA, E., DOBRINAS, S., NEGREANU-PIRJ OL, T., Rev. Chim.(Bucharest), 61, no. 1, 2010, p. 41.

16.STANCIU, G., CRISTACHE, N., LUPSOR, S., DOBRINAS, S., Rev. Chim. (Bucharest), 68, no. 7, 2017, p. 1429.

17.CHENA, G.-L., CHENA, S.-G., XIAOB, Y., FU, N.-L., Industrial Crops $\&$ Products, 111, 2018, p. 430.

18.DIF, M.M., BENYAHIA, M., TOUMI BENALI, F., RAHMANI, M., BOUAZZA, S., Phytotherapie, 15, 2017, p. 367.

19.MASLENNIKOV, P.V., CHUPAKHINA, G.N., SKRYPNIK, L.N., Biology Bulletin, 41, no. 2, 2014, p. 133.

20.POMBAL, S., RODRIGUES, C.F., ARAUJ O, J. P., PEDRO, P. M., JESUS M. RODILLA, J.M., DIEZ, D. GRANJA, A. P., GOMES A.C., SILVA, L.A., Springer Plus, 5, 2016, p. 1711.

21.SPIRIDON, I., BODIRLAU, R., TEACA, C.-A., Cent. Eur. J. Biol., 6, no. 3,2011, p. 388.

$\overline{\text { Manuscript received: } 26.07 .2018}$ 